\title{
Resurrection plants: Imperative resources in developing strategies to drought and desiccation pressure
}

\author{
Afroz Alam $^{1 *}$, Ananya Dwivedi ${ }^{1}$ \& Iwuala Emmanuel ${ }^{2}$ \\ ${ }^{1}$ Department of Bioscience and Biotechnology, Banasthali Vidyapith, India \\ ${ }^{2}$ Department of Plant Science, Federal University OyeEkiti, Nigeria
}

\section{Article history}

Received: 30 March 2019

Accepted: 28 April 2019

Published: 23 July 2019

\begin{abstract}
Resurrection plants are the vital assets of nature that have amazing mechanism to restrict the negative impacts of drought or desiccation stress by diminishing cell damage. These surprising plants are in minority on this planet but have the potential to serve as a powerful resource for developing new strategies for major crop plants that are unable to adapt well to the arid climate. In this review, an attempt is made to highlight the potential aspects of these resurrection plants especially the genetic engineering facet which has been done to develop drought tolerance in economically important plants.
\end{abstract}

Keywords: resurrection; poikilohydry; stress; tolerance.

Citation: Alam A, Dwivedi A, Emmanuel I. Resurrection plants: Imperative resources in developing strategies to drought and desiccation pressure. Plant Science Today 2019;6(3):333-341. https://doi.org/10.14719/pst.2019.6.3.542

Copyright: ( ) Alam et al (2019). This is an open-access article distributed under the terms of the Creative Commons Attribution License, which permits unrestricted use, distribution, and reproduction in any medium, provided the original author and source are credited (https://creativecommons.org/licenses/by/4.0/).

Indexing: Plant Science Today is covered by Scopus,Web of Science, BIOSIS Previews, ESCI, CAS, AGRIS, CABI, Google Scholar, etc. Full list at http://www.plantsciencetoday.online

\section{Introduction}

Stress is an "undeniable pressure of some antagonistic force", that leads to the alteration or inhibition in the typical functioning of the system. Drought is considered as one of the most important stresses imposed by the environment that delimits the growth and development of plant. Consequently, impairs performance and modulates the production of cash crops more than any other factor (1). Drought stress is either encountered by the plant when there is limitation in water supply to the roots or when the transpiration rate becomes very high. To neutralize severe damages caused by drought, plants employ a range of metabolic adjustment to preserve regular functioning.
Drought tolerance is the level at which there is an adaptation in the arid and water deficit conditions. This mechanism is attributed by osmotic adjustment which involves inorganic ions, organic acids and carbohydrates and the alteration in the elasticity of cells and tissues. Desiccation tolerance is the property of plants to survive in less or almost nil cellular water level and to revive all lost protoplasmic water upon rehydration (2). Resurrection plants are those plants which have the ability to produce pollen or seeds which are tolerant to desiccation and possess vegetative tissues that can tolerate desiccation. They are widely distributed in different taxa varying from pteridophytes to dicotyledons except for the 
Table 1. List of some widely studied resurrection plants (14)

\begin{tabular}{|c|c|c|c|c|c|}
\hline $\begin{array}{l}\text { Sl. } \\
\text { No }\end{array}$ & Name & Family & $\begin{array}{l}\text { Monocot/ } \\
\text { Dicot/others }\end{array}$ & Origin & $\begin{array}{l}\text { Poikilochloro } \\
\text { phyllous (P) / } \\
\text { Homoiochloro } \\
\text { phyllous (H) }\end{array}$ \\
\hline 1 & Xerophyta viscosa Baker & Velloziaceae & Monocot & Southern Africa & $\mathrm{P}$ \\
\hline 2 & Xerophyta humulis (Baker) T. Durand \& Schinz & Velloziaceae & Monocot & Southern Africa & $\mathrm{P}$ \\
\hline 3 & Mysothamnus flabellifolius Welw. & Myrothamnaceae & Dicot & Southern Africa & $\mathrm{H}$ \\
\hline 4 & Sporobolus stapfianus Gand. & Poaceae & Monocot & Southern Africa & \\
\hline 5 & Eragrostis nindensis Ficalho \& Hiern & Poaceae & Monocot & Southern Africa & \\
\hline 6 & Craterostigma plantagineum Hochst. & Scrophulariaceae & Dicot & Southern Africa & $\mathrm{H}$ \\
\hline 7 & Craterostigma wilmsii Engl. & Scrophulariceae & Dicot & Southern Africa & $\mathrm{H}$ \\
\hline 8 & Lindernia brevidens Skan & Linderniaceae & Dicot & East Africa & $\mathrm{H}$ \\
\hline 9 & Boea hygrometrica (Bunge) R. Br. & Gesneriaceae & Dicot & China & $\mathrm{H}$ \\
\hline 10 & Bornetella nitida Munier-Chalmas ex Sonder & Dasycladaceae & Dicot & $\begin{array}{l}\text { Africa, Australia, } \\
\text { Asia }\end{array}$ & $\mathrm{H}$ \\
\hline 11 & Selaginella lepidophylla (Hook. \& Grev.) Spring & Selaginellaceae & Pteridophyta & $\begin{array}{l}\text { North and South } \\
\text { America }\end{array}$ & \\
\hline 12 & Tortula ruralis (Hedw.) Gaertn., Meyer \& Scherb. & Pottiaceae & Bryophyta & North America & \\
\hline
\end{tabular}

gymnosperms (3,4). Farrant and Moore (2011) quoted "genes that ensure desiccation tolerance are present in all plants, but are utilized mostly when they produce seeds (5). On the other hand resurrection plants are able to switch on these genes in their leaves and roots whenever there is drought stress". Tolerance against desiccation in resurrection plants was acquired at the latter stages of organismal complexity through the evolution of various metabolic and structural protective mechanisms. These are because either of the combination of ubiquitous housekeeping mechanisms or by the invention of genes that are specific for a particular species like CDT-1 gene in Craterostigma plantagineum (6-8).

Places which observe scanty and occasional rainfall are the natives for resurrection plants. Under these adversities they can tolerate by being dry for a wide temperature ranges, where they experience repeated cycle of drying and dehydration all around the year $(8,9)$. Southern hemisphere region of Africa, Australia, India and South America are the places where most resurrection plants have been reported (10). Initially in 1970s most of the resurrection plants were described (3, 11-14). Resurrection plants are found both in the monocot and dicot plants. Dicot families such as Linderniaceae, Scrophulariaceae, and Myrothamnaceae show the presence of resurrection plants while they are more scattered among the monocot families (Table 1). Genera viz., Craterostigma and Lindernia represents desiccation-tolerant plants which was suggested by the first phylogenetic analysis among the Scrophulariaceae (15).

\section{Strategies in resurrection plants against desiccation}

\section{Morphological changes upon desiccation}

Morphology is greatly affected during water deficit conditions in resurrection plants. Leaf curling and folding is the most obvious response during desiccation (16-20). UV radiation causes damage by oxidative stress which can be limited by leaf folding hence it is an important adaptation upon desiccation. Craterostigma wilmsii or $C$. plantagineum leaves, are curled inwards during stress. They become tightly folded in such a manner that the abaxial surfaces of mature leaves present in the outer whorl exposed to direct sunlight (Fig. 1) (21, 22). Flat and grass like leaves are observed in $X$. humilis. In desiccated conditions, the folding in the leaf blades are half along the midrib and only the abaxial surface is exposed to direct sunlight $(21,23)$.

\section{Membrane flexibility and fluidity}

Inward shrinking of the central vacuole due to the loss of water causes withdrawal of the cellular contents which leads to a reduction in elasticity between plasmalemma and cell wall. These are lethal when the plasmodesmatal connections are broken (24). Resurrection plants are adapted to protoplast shrinkage undergoes extensive folding in its cell wall, this leads to the constriction of the cell and prevents the plasmalemmato tear from the cell wall $(22,25-28)$. This leads to the reduction for the capacity of irreversible mechanical damage phenomenon and avoids the negative turgor pressure to develop (29). In the cell wall of $C$. wilmsii, there is a significant level of increment in un-esterified pectins and xyloglucans during 
desiccation (27). In Boea hygrometrica cell wall flexibility has been correlated with the increase in a glycine-rich protein (30). Membrane fluidity is the result of high degree of poly unsaturation in membrane phospholipids (31).

\section{Photosynthetic capacity of resurrection plants}

Resurrection plants modulate their photosynthetic machinery during dehydration either by shutting it completely or operating it in a passive mode to avoid the accumulation of reactive oxygen species (ROS). In Boea hygrometrica and Haberlea rhodopensis ratio of pigment-protein complexes and the integrity of thylakoids were maintained while there were changes in carbon fixation and disruption in the functions of photosystem II (PSII) (32-33). The decrease of $\mathrm{CO}_{2}$ assimilation due to the closure of stomata down regulates the activity of PSII. Non photochemical quenching is triggered in leaves of Ramonda serbica to control the formation of ROS and to protect the integrity of membrane (34). Dehydration affects the occupation of the enzymes involved in Calvin cycle more pronouncedly than the enzymes involved in electron transport chain (35).

\section{Homoiochlorophyllous species and Poikilo- chlorophyllous species: Two schemes undertaken by resurrection plants to combat oxidative damage}

Homoiochlorophyllous species are able to employ the chlorophyll and the thylakoid membranes, while a slight change in the distribution of photosynthetic pigments is being observed (36).
Chloroplasts are modulated during dehydration. They become orbicular with alteration in inner membranes and stacking. The ratio of lipids and proteins is also altered $(22,26,37-38)$. In poikilochlorophyllous species, the photosystem complexes and chlorophyll are broken down (T). Accumulation of toxic reactive oxygen species is avoided by the decadence of chlorophyll. Poikilochlorophyllous plants are slower in resuming photosynthesis than homoiochlorophyllous plants as they synthesize all cellular components over again. In comparison with Poikilochlorophyllous plants, Homoiochlorophyllous plants require an effective antioxidant protection in opposition to free radicals (33). HDT (homoiochlorophyllous desiccation-tolerant) plants minimize the production of reactive oxygen species not only by the folding of leaves to prevent the interaction between light and chlorophyll but also by alternative mechanisms as well.

The first mechanism is the scavenging of reactive oxygen species through antioxidant enzymes and metabolites which helps to protect the plant during desiccation (18). Second mechanism is the accumulation of xanthophylls or anthocyanins which ultimately minimizes ROS formation $(21,22)$.

The final two mechanisms through which homoiochlorophyllous plants reduce ROS development include downregulating the formation of gene products, which is related with photosynthesis, such as Chlorophyll a/b-binding
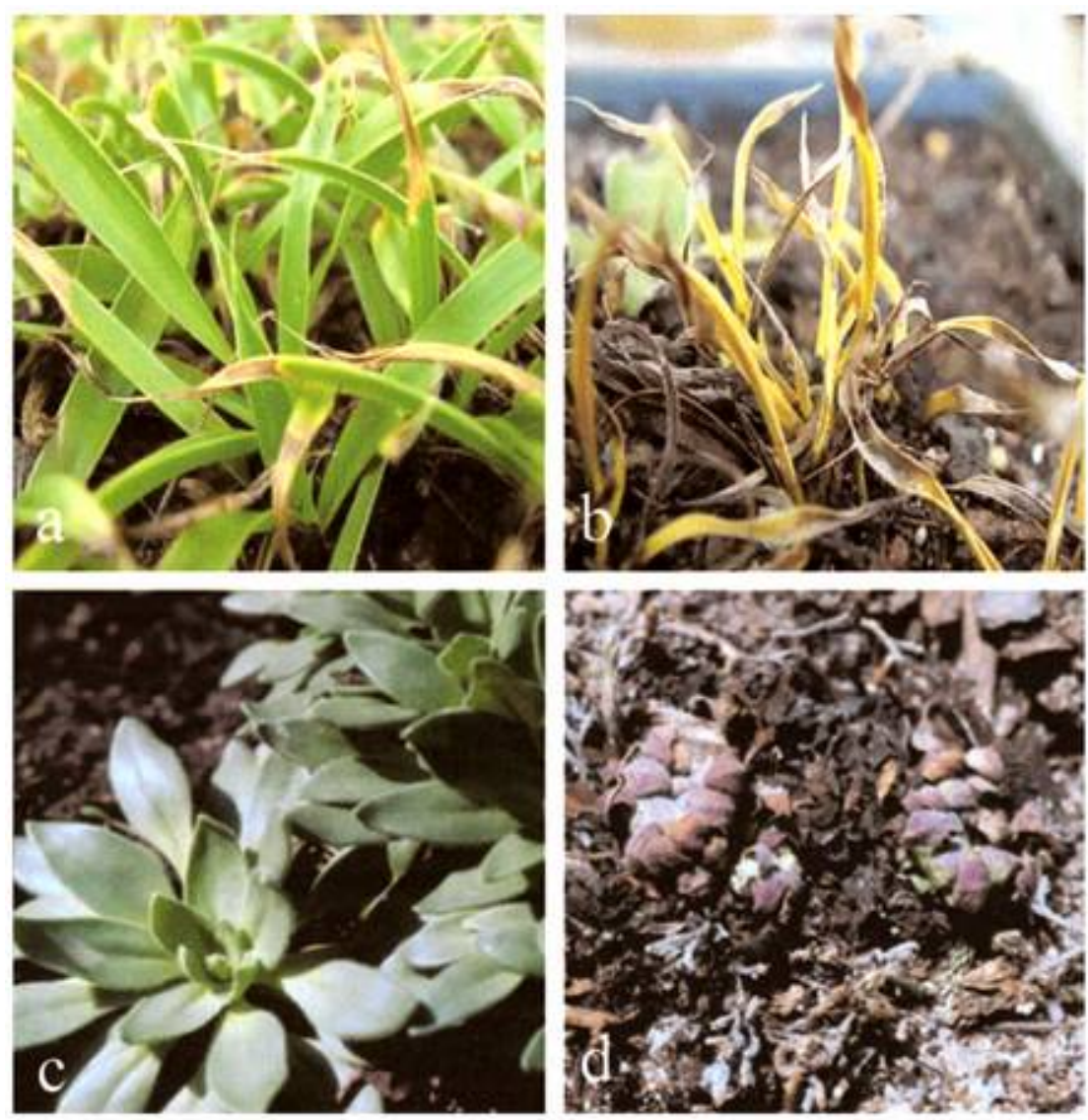

Fig. 1. Variation in the morphology of resurrection plants Xerophyta humilis (a and b) and Craterostigma plantigenum (c and d). 
protein, RuBisCO large subunit (rbcl), or oxygenevolving complex (40) and the initiation of shielding proteins such as early light-inducible proteins $(36,41)$. Thylakoid chlorophyll binding proteins (ELIPs) are being demonstrated transiently during the de etiolation of etiolated plants (42). Mature leaves, when exposed to excessive sunlight and other abiotic stresses start the formation of ELIPs, which consequently leads to the amplification of ROS (43-47). In the leaves of C. plantagineum an unusual gene family has been indicated in response to desiccation (48). The genes that encode plastid-targeted proteins (CpPTP), are capable to negotiate with plastid DNA and protect it against dehydration.

\section{Antioxidant enzymes protection}

Establishment of numerous antioxidant protective mechanism is correlated with recovery in resurrection plants during desiccation and preserve them upon rehydration $(49,50)$. High concentrations of chlorophyll is retained in $M$. flabellifolius during desiccation. When it is rehydrated, antioxidants such as a-tocopherol, ascorbate and glutathione are accumulated in different tissues. In the recovery pathway, antioxidants are an essential component. It is observed in plants, which are unable to recover from desiccation because antioxidants are broken down due to long exposures of light (49). A novel antioxidant enzyme induced by desiccation corresponding to a type of 1-cys peroxiredoxin (Prxs) was identified in the leaves of $X$. viscosa (5152). In substrates such as hydroperoxides they are found to be active (53).

\section{Abscisic acid role in desiccation tolerance pathways}

Water deficiency induces the stomata to close and scope for the assimilation of carbon is reduced, which in turn results in the non-availability of electron acceptor (NADP) and consequently leads to the formation of free radicals (54-58). Abscisic acid (ABA), is the phytohormone that aids in the regulation of the pore size of stomata and regulates the inlet of $\mathrm{CO}_{2}$ and the outlet of water from the leaf. By the action of ABA pores of stomata close in response to drought stress, this leads to an increment in cytosolic calcium concentrations via Hydrogen peroxide $\left(\mathrm{H}_{2} \mathrm{O}_{2}\right)$ activated channels and release from the vacuole and other intracellular stores (58-59). Particularly $\mathrm{H}_{2} \mathrm{O}_{2}$ is thought to have a role in signalling in guard cells , stimulates the anion channels in the plasma membrane, ending into guard cell depolarization, efflux of potassium ions and depletion of turgidity and volume, concluding in the termination of stomata (60). This also leads to the activation of ROS in guard cells, enabling the stomata to shut down. ABA is an important hormone which is useful in attaining tolerance against desiccation and also stimulates the synthesis of desiccation induced proteins in most of the resurrection plants including the aquatic species Chamaegigas intrepidus (16, 61-66).

\section{Carbohydrate metabolism}

It is commonly pragmatic that the accumulation of soluble sugars during the desiccation process has is significance to provide tolerance during stress. Glucose is formed rapidly from starch during desiccation (67). Functions of sugars include osmotic adjustments during dehydration and stabilization of proteins in the dehydrated cells (68). Protein denaturation and membrane fusions are prevented by sucrose and trehalose $(67,69)$. They have the capacity to form bioglasses (vitrification) within the dried cell. Sugars are not solemnly responsible for the glass formation in the cytoplasm. It may be due to the interactions between sugars and supplementary molecules, probably with proteins (70). The production of free radicals is limited and slowed by chemical revulsion and molecular dissipation in cytoplasm in the process of vitrification (70). Hence, it is evident that vitrification holds an important place in the protection of resurrection plants. Sucrose level exceeds in dry leaves and becomes a potent sugar during dehydrated condition in S. stapfianus while in the hydrated state glucose, fructose, and galactose are present in large amounts (71). An eight-carbon sugar 2-octulose, is predominantly found in hydrated leaves of $C$. plantagineum, which is transformed to sucrose upon rehydration (72). While, stachyose is accumulated in the roots of drying plant. Sucrose biosynthetic genes are induced in $C$. plantagineum by both desiccation and abscisic acid (73). Transketolase contributes to the conversion of octulose to sucrose.

\section{Proteins having protective properties}

At the molecular level, a marked build up of stress related proteins is the most obvious change during dehydration. Majority of these are Late Embryogenesis Abundant (LEA) proteins. The ability to uphold the usual metabolism without any irreversible damage during extreme scarcity of cellular water level is known as desiccation tolerance (2). There is principally high levels of LEA protein mRNAs exist in the dehydrated mature embryos, whereas, during late embryogenesis stage, the transcripts of storage protein genes are completely degraded. These proteins operate as molecular chaperones and play dominant roles in biosynthesis of proteins, folding, assembly, intracellular localization, secretion, and degradation of other proteins (74). They also act as stabilizers, hydration buffers, antioxidants, membrane protectants, organic glass formers and ion chelators (75).

Besides LEA proteins, heat shock proteins (Hsps) are also linked with desiccation. Usually, Hsps have the ability to maintain protein partners in a folded or unfolded nature, reduces the accumulation of external proteins and are 
removed from the cell as they tend to disturb its proper functioning (74).

\section{Rehydration}

The mechanism of rehydration was in some ways have been overlooked in the discovery of resurrection plants. Rehydration involves a slow retrieval of cellular kinetics, which ultimately leads to the reactivation of normal metabolic functions. The entire desiccation tolerance is based on the reestablishment of metabolic activities and important functions.

A discrete period of time is required for the successful rehydration in $C$. plantagineum (63). A complete uptake of water for $12-15 \mathrm{~h}$ is required by dried Craterostigma plants for its rehydration. There were no detection of new mRNAs during the early stages of rehydration from protein assays (76). mRNAs and enzymes which are important for the restoration of respiration, photosynthesis and other metabolic pathways were sufficiently protected in the dehydrated condition. Processes for averting repair mechanism of cell damage upon rehydration were found in resurrection plants (77). Proteins such as EXPANSINs play vital role in rehydration (78). AQUAPORINs are important for regulating the rate of flow of water inside the cells upon rehydration and produce and store mRNAs during the last stage of drying (78).

\section{Signalling mechanisms in resurrection plants}

In response to water deficiency, there is an immense transcriptional reprogramming. ABA, lipid messengers or alterations in the redox components are some types of signalling molecules present in resurrection plants $(47,79)$. Induction of various protective mechanism including inhibition of photosynthesis and retardation of growth are due to the presence of transcription factors from different families (47, 79-81).

In Boea hygrometrica, the synthesis of raffinose and raffinose family oligosaccharides (RFOs) in an ABA dependent manner. It is due to transcription factor (WRKY) which attaches to a Wbox promoter element of the galactinol synthase gene (30).

In C. plantagineum CPMYB10, transcription factor from the Myb family, not only binds to and regulates its own promoter but also the promoter of the late embryogenesis abundant gene ( $L E A$ gene $\mathrm{Cp11-24).} \mathrm{It} \mathrm{functions} \mathrm{as} \mathrm{an} \mathrm{activator} \mathrm{stressed}$ tissue and as a repressor in non-stressed tissues (81). In leaves and roots of Xerophyta humilis, vicinaloxygen chelate (VOC) metalloenzyme superfamily are being upregulated during desiccation $(82,83)$.

\section{Transcriptome profiling in resurrection plants}

Transcripts of two dicot resurrection plant species namely C. plantagineum and Haberlia rhodopensis were sequenced from their different physiological stages. This allowed the coverage of the entire genome of the transcripts in species with genomes which are still not be sequenced. Transcript sequences of these two resurrection plants are similar to genes from castor bean (Ricinus communis), poplar (Populus trichocarpa) and grapevine (Vitis vinifera). Gene ontology analysis identified categories prominently represented in particular conditions. Genes in unstressed samples of both species were related with growth, cell wall organization and photosynthesis. While genes recovered after dehydration were namely sucrosesynthase, chromosome scaffolded proteins. While many proteins related with stress are known, including various LEA proteins, LIPOCALIN, a GABA transaminase and pathogenesis-related (PR) proteins. A range of signalling related genes encoding proteins have been reported that are associated with calcium channeling and ABA signalling in $C$. plantagineum (63). In $H$. rhodopensis LEA proteins, catalase genes, early light inducible proteins (ELIPs), heat shock factors, protein phosphatase genes have been recognized $(36,84)$.

\section{Cconclusion}

In today's scenario where human population is increasing minute by minute which is ultimately leading to damage to the ecosystem intentionally or unintentionally. Drought is one such damage which is a threat to agriculture. Genes from resurrection plants have the potential for molecular improvement in crop species which are subjected to drought and desiccation. Hence, resurrection plants are considered as the model plant for drought tolerance. To engineer desiccation tolerance in different species there is a requirement of a complex approach. Results of the past molecular experiments suggest that there are some novel genes in resurrection species but that almost all products and by-products of gene which are being expressed are correlated to desiccation tolerance and have their substitutes in nondesiccation tolerant plant species. Examples of these novel proteins and metabolites are the hydrophilic protein CpEdi-9 from $C$. plantagineum (85) and 3,4,5-tri-O-galloylquinic acid which is being isolated from M. flabellifolia (86). Desiccation tolerance in resurrection plants is due to the combined effect of the collection of antioxidants and different osmo-protective compounds namely sugars (sucrose and raffinose), trehalose, some hydrophilic proteins such as LEA proteins. Poikilochlorophyllous and homiochlorophyllous resurrection plants have different machineries which help them against desiccation. Resurrection plants in expense to extreme stress grow slowly this enables their protection against desiccation and helps in the formation of genes that response to stress. Dehydration/rehydration responses and functional analysis of genes (87) aid us in understanding unique cellular processes of tolerance in resurrection plants which aimed to 
serve as the base for improvement in vital crop species at the molecular level.

\section{Acknowledgements}

The authors wish to acknowledge the Vice Chancellor, Banasthali Vidyapith, Rajasthan for his support related to this study.

\section{Conflict of Interest}

Authors declare no conflict of interest.

\section{Authors' contributions}

All the authors contributed equally to the work presented in this paper.

\section{References}

1. Shao HB, Chu LY, Jaleel CA. Understanding water deficit stress-induced changes in the basic metabolism of higher plants-biotechnologically and sustainably improving agriculture and the eco environment in arid regions of the globe. Critical Reviews in Biotechnology 2009; 29: 131-151. https://doi.org/10.1080/07388550902869792

2. Leprince O, Buitink J. Desiccation tolerance: From genomics to the field. Plant Science 2010; 179: 554-564. https://doi.org/10.1016/j.plantsci.2010.02011

3. Gaff DF. Desiccation-tolerant flowering plants in Southern Africa. Science 1971; 174: 1033-1034. https:// doi.org/10.1126/science.174.4013.1033

4. Oliver MJ. Desiccation tolerance in vegetative plant cells. Physiologia Plantarum 1996; 97: 779-787. https:// doi.org/10.1111/j.1399-3054.1996.tb00544.x

5. Farrant JM, Moore JP. Programming desiccationtolerance: from plants to seeds to resurrection plants. Current Opinion in Plant Biology 2011; 14(3): 340-345. https://doi.org/10.1016/j.pbi.2011.03.018

6. VanBuren R, Wai, CM, Ou S, Pardo J, Bryant D, Ning Jiang N,Todd C. Mockler TC, Patrick Edger P, Todd P. Michae TP. Extreme haplotype variation in the desiccation-tolerant clubmoss Selaginella lepidophylla. Nature Communications 2018; 9:13. https://doi.org/10.1038/s41467-017-02546-5

7. Illing N, Denby KJ, Collett H, Shen A, Farrant JM. The signature of seeds in resurrection plants: a molecular and physiological comparison of desiccation tolerance in seeds and vegetative tissues. Integrative and Compartaive Biology 2005; 45: 771-787. https://doi.org/ $\underline{10.1093 / \mathrm{icb} / 45.5 .771}$

8. Furini A, Koncz C, Salamini F, Bartels D. High level transcription of a member of a repeated gene family confers dehydration tolerance to callus tissue of Craterostigma plantagineum. The EMBO Journal. 1997; 16: 3599-3608. https://doi.org/10.1093/emboj/16.12.3599

9. Bartels D, Salamini F. Desiccation tolerance in the resurrection plant Craterostigma plantagineum. A contribution to the study of drought tolerance at the molecular level. Plant Physiology 2001; 127: 13461353.
10. Mundree SG, Baker B, Mowla S, Peters S, Marais S, Vander Willigen $\mathrm{C}$, et al. Physiological and molecular insights into drought tolerance. African Journal of Biotechnology 2002; 1:28-38.

11. Moore JP, Lindsey FJM, GG BWF. The South African and Namibian populations of the resurrection plant Myrothamnus flabellifolius are genetically distinct and display variation in their galloquinic acid composition. Journal of Chemical Ecology 2005; 31: 2823-2834. https://doi.org/10.1007/s10886-005-8396-x

12. Gaff DF, Ellis RP. Southern African grasses with foliage that revives after dehydration. Bothalia 1974; 11: 305308.

13. Gaff DF, Churchill DM. Borya nitida Labill. - an Australian species in the Liliaceae with desiccationtolerant leaves. Australian Journal of Botany 1976; 24: 209-224.

14. Gaff DF, Latz PK. The occurrence of resurrection plants in the Australian flora. Australian Journal of Botany 1978; 26: 485-492.

15. Rahmanzadeh $\mathrm{R}$, M€uller $\mathrm{K}$, Fischer $\mathrm{E}$, Bartels $\mathrm{D}$, Borsch T. The Linderniaceae and Gratiolaceae are further lineages distinct from the Scrophulariaceae (Lamiales). Plant Biology 2005; 7: 1-12. https://doi.org/10.1055/s-2004-830444

16. Bartels D, Hussain SS. Resurrection Plants: Physiology and Molecular Biology. U. L€uttge et al. (eds.). Plant Desiccation Tolerance. Ecological Studies 2011; 215: 339-364. https://doi.org/10.1007/978-3-642-19106-0 16

17. Gaff DF. Responses of desiccation tolerant 'resurrection'plants to water stress. In: Kreeb $\mathrm{KH}$, Richter H, Hinckley TM, eds. Structural and functional responses to environmental stresses. The Hague: SPB Academic Publishing. 1989; pp. 255-268.

18. Scott P. Resurrection plants and the secrets of eternal leaf. Annals of Botany 2000; 85: 159-166.

19. Farrant JM, Vander Willigen C, Loffell DA, Bartsch S, Whittaker A. An investigation into the role of light during desiccation of three angiosperm resurrection plants. Plant Cell and Environment 2003; 26: 12751286. https://doi.org/10.1046/j.00168025.2003.01052.X

20. Vander Willigen C, Pammenter CNW, Jaffer MA, Mundree SG, Farrant JM. An ultrastructural study using anhydrous fixation of Eragrostis nindensis, a resurrection grass with both desiccation-tolerant and sensitice tissues. Functional Plant Biology 2003; 30: 110.

21. Farrant JM, Brandt W, Lindsey GG. An overview of mechanisms of desiccation tolerance in selected angiosperm resurrection plants. Plant Stress 2007; 1(1): $72-84$.

22. Sherwin HW, Farrant JM. Protection mechanisms against excess light in the resurrection plants Craterostigma wilmsii and Xerophyta viscosa. Plant Growth Regulations 1998; 24: 203-210.

23. Farrant JM. A comparation of mechanisms of desiccation tolerance among three angiosperm resurrection plant species. Plant Ecology 2000; 151: 2939.

24. Hallam ND, Luff SE. Fine structural changes in the mesophyll tissue of the leaves of Xerophyta villosa during desiccation. Botanical Gazette 1980; 141: 173179. 
25. Cosgrove DJ. Expansive growth of plant cell walls. Plant Physiology and Biochemistry 2000; 38: 109-124.

26. Farrant JM, Sherwin HW. Mechanisms of desiccation tolerance in seeds and resurrection plants. In: Taylor AG, Huang XL (eds) Progress in seed research. Proceedings of the second international conference on seed science and technology. Communication Services of the New York State Agricultural Experimental Station, Geneva, 1997; NY. pp. 109-120.

27. Thomson WW, Platt KA. Conservation of cell order in desiccated mesophyll of Selaginella lepidophylla [Hook and Grev.] Spring. Annals of Botany 1997; 79: 439-447.

28. Vicrè M, Sherwin HW, Driouich A, Jaffer MA, Farrant JM. Cell wall characteristics and structure of hydrated and dry leaves of the resurrection plant Craterostigma wilmsii, a microscopical study. Journal of Plant Physiology 1999; 155: 719-726.

29. Vicrè M, Lerouxel O, Farrant J, Lerouge P, Driouich A. Composition and desiccationinduced alterations of the cell wall in the resurrection plant Craterostigma wilmsii. Physiologia Plantarum 2004; 120: 229-239.

30. Vander Willigen C, Farrant JM, Pammenter NW. Anomalous pressure volume curves of resurrection plants do not suggest negative turgor. Annals of Botany 2001; 88: 537-543.

31. Wang Z, Zhu Y, Wang L, Liu X, LiuY, Phillips J, et al. A WRKY transcription factor participates in dehydration tolerance in Boea hygrometrica by binding to the Wbox elements of the galactinol synthase (BhGols1) promoter. Planta 2009; 230: 1155-1166. https://doi.org/ $\underline{10.1007 / \mathrm{s} 00425-009-1014-3}$

32. Moon BY, Higashi S, Gombos Z, Murata N . Unsaturation of the membrane lipids of chloroplasts stabilizes the photosynthetic machinery against lowtemperature photoinhibition in transgenic tobacco plants. Proceedings of the National Academy of Sciences of the United States of America. 1995; 92(14): 6219-6223. 10.1073/pnas.92.14.6219 https://doi.org/

33. Georgieva K, Szigeti Z, Sarvari E, et al. Photosynthetic activity of homoiochlorophyllous desiccation tolerant plant Haberlea rhodopensis during dehydration and rehydration. Planta 2007; 225: 955-964. https://doi.org/ 10.1007/s00425-006-0396-8

34. Deng $\mathrm{X}$, Hu ZA, Wang HX, et al. A comparison of photosynthetic apparatus of the detached leaves of the resurrection plant Boea hygrometrica with its non tolerant relative Chirita heterotrichia in response to dehydration and rehydration. Plant Science 2003; 165: 851-861. 9452(03)00284-X

35. Degl'Innocenti, Guidi EL, Stevanovic B, Navari F. $\mathrm{CO}_{2}$ fixation and chlorophyll a fluorescence in leaves of Ramonda serbica during a dehydration rehydration cycle. Journal of Plant Physiology 2008; 165: 723-733. https://doi.org/10.1016/j.jplph.2007.06.009

36. Schwab KB, Schreiber U, Heber U. Response of photosynthesis and respiration of resurrection plants to desiccation and rehydration. Planta 1989; 177: 217227.

37. Alamillo JM, Bartels D. Effects of desiccation on photosynthesis pigments and the ELIP-like dsp22 protein complex in the resurrection plant Craterostigma plantagineum. Plant Science 2001; 160: 1161-1170.
38. Navari-Izzo F, Quartacci MF, Pinzino C, Rascio N, Vazzana C, Sgherri C. Protein dynamics in thylakoids of the desiccation-tolerant plant Boea hygroscopica during dehydration and rehydration. Plant Physiology 2000; 124: 1427-1436.

39. Quartacci MF, Forli M, Rascio N, DallaVecchia F, Bochicchio A, Navari-Izzo F. Desiccation-tolerant Sporobolus stapfianus: lipid composition and cellular ultrastructure during dehydration and rehydration. Journal of Experimental Botany 1997; 48: 1269-1279.

40. Tuba Z, Proctor MCF, Csintalan Z. Ecophysiological responses of homoiochlorophyllous and poikilochlorophyllous desiccation-tolerant plants: a comparison and an ecological perspective. Plant Growth Regulation 1998; 24: 211-217.

41. Gechev ST, Challabathula D,Benina M, Toneva V, Bartels D. Molecular mechanisms of desiccation tolerance in resurrection plants. Cellular and Molecular Life Sciences 2012; 69: 3175-3186. https://doi.org/10.1007/s00018-012-1088-0

42. Araùjo SS, Duque AS, Silva JM, etal. Water deficit and recovery response of Medicago truncatula plants expressing the ELIP-like DSP22. Biologia Planarum 2013; 57: 159-163. https://doi.org/10.1007/s10535-012$\underline{0235-7}$

43. Adamska I. ELIPs: Light-induced stress proteins. Physiologia plantarum 1997; 100: 794-805.

44. Montanè MH, Dreyer S, Triantaphylides C, Kloppstech K. Early light-inducible proteins during long-term acclimation of barley to photooxidative stress caused by light and cold: high level of accumulation by posttranscriptional regulation. Planta 1997; 202: 293302.

45. Zeng Q, Chen XB, Wood A J. Two early light-inducible protein (ELIP) cDNAs from the resurrection plant Tortula ruralis are differentially expressed in response to desiccation, rehydration, salinity, and high light. Journal of Experimental Botany 2002; 53(371): 11971205.

46. Provart NJ, Gil P, Chen W, Han B, Chang HS, Wang X, Zhu T. Gene expression phenotypes of Arabidopsis associated with sensitivity to low temperatures. Plant Physiology 2003; 132: 893-906. https://doi.org/10.1104/ pp.103.021261

47. Sävenstrand $H$, Olofsson M, Samuelsson M, Strid A. Induction of early-inducible protein gene expression in Pisum sativum after exposure to low levels of UV-B radiation and other environmental stresses. Plant Cell Reports 2004; 22: 532-536. https://doi.org/10.1007/s00299-003-0743-1

48. Phillips JR, Hilbricht T, Salamini F, Bartels D. A novel abscisic acid- and dehydration responsive gene family from the resurrection plant Craterostigma plantagineum encodes a plastid-targeted protein with DNA binding activity. Planta 2002; 215:258-266. https:// doi.org/10.1007/s00425-002-0755-Z

49. Challabathula D, Puthur JT, Bartels D. Surviving metabolic arrest: photosynthesis during desiccation and rehydration in resurrection plants. Annals of the New York Academy of Sciences 2016; 1365: 89-99. https://doi.org/10.1111/nyas.12884

50. Kranner I, Beckett RP, Wornik S, Zorn M, Pfeinhofer W. Revival of a resurrection plant correlates with its antioxidant status. The Plant Journal 2002; 31: 13-24.

51. Kranner I, Birtić S. A modulating role for antioxidants in desiccation tolerance. Integrative and Comparative 
$\begin{array}{lcr}\text { Biology } & 2005 ; & 45: \\ \text { https://doi.org/10.1093/icb/45.5.734 }\end{array}$

52. Ndima T, Farrant JM, Thomson J, Mundree $\mathrm{S}$. Molecular characterization of XVT8, a stressresponsive gene from the resurrection plant Xerophyta viscosa Baker. Plant Growth Regulation 2001; 35: 137-145.

53. Mowla SB, Thomson JA, Farrant JM, Mundree SG. A novel stress-inducible antioxidant enzyme identified from the resurrection plant Xerophyta viscosa Baker. Planta 2002; 215: 716-726. https://doi.org/10.1007/s00425-002-0819-0

54. Kozak CA. Genetic mapping of six mouse peroxiredoxin genes and fourteen peroxiredoxin related sequences. Mammalian Genome 1999; 10: 1017-1019.

55. Smirnoff N. The role of active oxygen in the response of plants to water deficit and desiccation. New Phytologist 1993; 125: 27-58. https://doi.org/10.1111/j.1469-8137.1993.tb03863.x

56. Asada K. The water-water cycle as alternative photon and electron sinks. Philosophical Transactions Royal Society of London B 2000; 355: 1419-1431. https://doi.org/10.1098/rstb.2000.0703

57. Sairam PK, Saxena DC. Oxidative stress and antioxidants in wheat genotypes: possible mechanism of water stress tolerance. Journal of Agronomy and Crop Science 2000; 184: 55-61. https://doi.org/10.1046/j.1439-037x.2000.00358.x

58. Reddy AR, Chaitanya KV, Vivekanandan M. Droughtinduced responses of photosynthesis and antioxidant metabolism in higher plants. Journal of Plant Physiology. 2004; 161: 1189-1202. https://doi.org/10.1016/j.jplph.2004.01.013

59. Price AH, Taylor A, Ripley SJ, Griffiths A, Trewavas AJ , Knight M. Oxidative signals in tobacco increase cytosolic calcium. The Plant Cell 1994; 6: 1301-1310. https://doi.org/10.1105/tpc.6.9.1301

60. Köhler B and Blatt MR. Protein phosphorylation activates the guard cell $\mathrm{Ca} 2+$ channel and is a prerequisite for gating by abscisic acid. The Plant Journal: for Cell and Molecular Biology 2002; 32: 185194.

61. Schroeder JI, Kwak JM, Allen GJ. Guard cell abscisic acid signalling and engineering drought hardiness in plants. Nature 2001; 410: 327-330. https://doi.org/10.1038/35066500

62. Gaff DF. Protoplasmic tolerance of extreme water stress. In: Turner NC, Kramer PJ (eds) Adaptation of plants to water and high temperature stress. Wiley, 1980; New York, 207-230.

63. Gaff DF, Loveys BR. Abscisic-acid content and effects during dehydration of detached leaves of desiccation tolerant plants. Journal of Experimental Botany 1984; 35: $1350-1358$.

64. Bartels D, Schneider K, Terstappen G, Piatkowski D, Salamini F. Molecular cloning of abscisic acidmodulated genes which are induced during desiccation of the resurrection plant Craterostigma plantagineum. Planta 1990; 181: 27-34.

65. Reynolds TL, Bewley JD. Abscisic acid enhances the ability of the desiccation tolerant fern Polypodium virginianum to withstand drying. Journal of Experimental Botany 1993; 44: 1771-1779.
66. Hellwege EM, Dietz KJ, Volk OH, Hartung W. Abscisic acid and the induction of desiccation tolerance in the extremely xerophilic liverwort Exormotheca holstii. Planta 1994; 194: 525-531.

67. Schiller P, Heilmeier H, Hartung W. Absisic acid (ABA) relations in the aquatic resurrection plant Chamaegigas intrepidus under naturally fluctuating environmental conditions. New Phytologist 1997; 136: 603-611. 8137.1997.00789.x

https://doi.org/10.1046/j.1469-

8. Crowe JH, Carpenter JF, Crowe LM. The role of vitrification in anhydrobiosis. Annual Reviews Plant Physiology 1998; 60: 73-103. https://doi.org/10.1146/annurev.physiol.60.1.73

69. Ramanjulu S, Bartels D. Drought- and desiccationinduced modulation of gene expression in plants. Plant Cell and Environment 2002; 25: 141-151.

70. Peters S, Mundree SG, Thomson JA, Farrant JM, Keller F. Protection mechanisms in the resurrection plant Xerophyta viscosa Baker: both sucrose and raffinose family oligosacharides (RFOs) accumulate in leaves in response to water deficit. Journal of Experimental Botany 2007; 58(8): 1947-1956. https://doi.org/10.1093/jxb/erm056

71. Hoekstra FA. Differential longevities in desiccated anhydrobiotic plant systems. Integrative and Comparative Biology 2005; 45: 725-733. https://doi.org/ $\underline{10.1093 / \mathrm{icb} / 45.5 .725}$

72. Ghasempour HR, Gaff DF, Williams RPW, Gianello RD. Contents of sugars in leaves of drying desiccationtolerant flowering plants, particularly grasses. Plant Growth Regulation 1998; 24: 185-191.

73. Bianchi G, Gamba A, Murelli C, Salamini F, Bartels D. Novel carbohydrate metabolism in the resurrection plant Craterostigma plantagineum. The Plant Journal 1991; 1: 355-359.

74. Kleines M, Elster RC, Rodrigo MJ, Blervacq AS, Salamini F, Bartels D. Isolation and expression analysis of two stress-responsive sucrose-synthase genes from the resurrection plant Craterostigma plantagineum (Hochst.). Planta 1999; 209: 13-24. https://doi.org/10.1007/s004250050602

75. Feder ME, Hofmann GE. Heat shock proteins, evolutionary and ecological physiology. Annual Review of Physiology 1999; 61: 243-282. https://doi.org/ 10.1146/annurev.physiol.61.1.243

76. Tunnacliffe A, Wise M. The continuing conundrum of the LEA protein. Die Naturwissenschaften 2007; 94: 791-812. https://doi.org/10.1007/s00114-007-0254-y

77. Bernacchia G, Salamini F, Bartels D. Molecular characterization of the rehydration process in the resurrection plant Craterostigma plantagineum. Plant Physiology 1996; 111: 1043-1050. https://doi.org/10.1104/pp.111.4.1043

78. Cooper K, Farrant JM. Recovery of the resurrection plant Craterostigma wilmsii from desiccation: protection versus repair. Journal of Experimental Botany 2002; 53: 1805-813. https://doi.org/10.1093/jxb/erf028

79. Mariaux JB, Bockel C, Salamini F, Bartels D. Desiccation and abscisic acid-responsive genes encoding major intrinsic proteins (MIP) from the resurrection plant Craterostigma plantagineum. Plant Molecular Biology 1998; 38: 1089-1099. https://doi.org/ 10.1023/A:1006013130681. 
80. Deng $\mathrm{X}$, Phillips J, Brautigam A, Engstrom $\mathrm{P}$, Johannesson $\mathrm{H}$, Ouwerkerk PB, et al. A homeodomain leucine zipper gene from Craterostigma plantagineum regulates abscisic acid responsive gene expression and physiological responses. Plant Molecular Biology 2006; 61: 469-489. https://doi.org/10.1007/s11103-006-0023-x

81. Zhu Y, Wang Z, Jing Y, Wang L, Liu X, Liu Y, Deng X. Ectopic over-expression of BhHsf1, a heat shock factor from the resurrection plant Boea hygrometrica, leads to increased thermotolerance and retarded growth in transgenic Arabidopsis and tobacco. Plant Molecular Biology 2009; 71: 451-467. https://doi.org/ 10.1007/s11103-009-9538-2

82. Frank W, Munnik T, Kerkmann K, Salamini F, Bartels D. Water deficit triggers phospholipase D activity in the resurrection plant Craterostigma plantagineum. The Plant Cell 2000; 12:111-124.

83. Mulako I, Farrant JM, Collett H, Illing N. Expression of Xhdsi-1VOC, a novel member of the vicinal oxygen chelate (VOC) metalloenzyme superfamily, is upregulated in leaves and roots during desiccation in the resurrection plant Xerophyta humilis Baker Dur and Schinz. Journal of Experimental Botany 2008; 59: 3885-3901. https://doi.org/10.1093/jxb/ern226
84. Rodriguez M C S, Edsgärd D, Hussain SS, Alquezar D, Rasmussen M, Gilbert T, et al. Transcriptomes of the desiccation-tolerant resurrection plant Craterostigma plantagineum. The Plant Journal 2010; 63: 212-228. https://doi.org/10.1111/j.1365-313X.2010.04243.x

85. Rodrigo MJ, Bockel C, Blervacq AS, Bartels D. The novel gene CpEdi-9 from the resurrection plant $C$. plantagineum encodes a hydrophilic protein and is expressed in mature seeds as well as in response to dehydration in leaf phloem tissues. Planta 2004; 219: 579-589. https://doi.org/10.1007/s00425-004-1264-Z

86. Moore JP, Westall KL, Ravenscroft N, Farrant J, Lindsey GG, Brandt W. The predominant polyphenol in the leaves of the resurrection plant Myrothamnus flabellifolius, 3,4,5-tri-Ogalloylquinic acid, protects membranes against desiccation and free radicalinduced oxidation. The Biochemical Journal 2005; 385: 301-308. https://doi.org/10.1042/BJ20040499

87. Adebusola A, Victor O, Emmanuel I, Alam A. Effect of nitrogen application on phytochemical production in Jatropha curcas L. (Angiosperms: Euphorbiaceae) during drought conditions. Plant Science Today 2019: 6(2): 183-189. https://doi,org/10.14719/pst.20196.2.523 